\title{
The influence of absorptive capacity, sources of information and technological acquisition in the technological innovation breadth of manufacturing companies
}

\author{
Javier Del Carpio Gallegos \\ Universidad Esan \\ Jhony Ostos Mariño \\ Universidad Esan \\ Kerstin Bremser \\ Pforzheim University
}

Received April 19, 2017; accepted May 25, 2018.

\begin{abstract}
This research analyzes innovation in Peru, one of the fastest growing economies in South America. The research focuses on how absorptive capacity, the degree of importance of sources of information, and technological acquisition help companies in the manufacturing sector to improve technological innovation breadth. The results of the research show that the absorptive capacity helps to improve the performance of the technological innovation breadth of both low tech and medium-low technological intensity companies as well as medium-high and high-tech technological intensity companies. On the other hand, there is a difference in the degree of importance assigned to the sources of information. In the case of companies of low and medium-low technological intensity, the information coming from consultants, commercial laboratories or private R \& D institutes has the greatest impact. Meanwhile, medium-high and high technological intensity companies attach greater importance to information coming from suppliers and consultants. In the companies of medium-high and high technological intensity is presented a greater importance of the technological acquisition in front of the companies of low and low-average technological intensity. The results show critical aspects of innovation in the manufacturing sector in Peru that provides implications for managers and researchers.
\end{abstract}

\section{KEYWORDS}

Absorptive capacity, technological innovation, and technological intensity.

JEL classification: O32, Q55. 


\section{Introduction}

In terms of the relationship between research and development ( R \& D) and innovation, the literature tends to focus its attention on high technology manufacturing companies. However, there are manufacturing companies who achieve innovations in their products and processes that are not related to specific R \& D activities (Santamaría, Nieto, \& Barge-Gil, 2009). It is just as important to analyze the behavior of these low and medium low technology (low- and medium-low-tech) companies due to their contribution to the growth of the economies in which they participate, the number of jobs they contribute, and the innovations introduced into the market (Heidenreich, Hirsch-Kreinsen, \& Jacobson, 2008). As such, low-tech companies remain central to the economic welfare of many. When measured in terms of results or capital invested, they dominate the economies of highly developed nations as well as developing countries, providing more than ninety percent of the gross product of the European Union, the United States and Japan (Robertson, Smith, \& Von Tunzelmann, 2009). Moreover, Krammer (2016) notes that "some of these mature industries still exhibit significant technology sales among leading companies, but more importantly, they form the backbone of all the economies in the world. Thus, understanding the motivation and benefits of such interactions can provide important lessons for policy-making for both developed and developing nations, where mature industries are still responsible for a considerable share of GDP and employment".

Thus, this article seeks to better understand the importance of low-and medium-low-tech company performance by setting the following objectives:

- To show how the absorptive capacity of low- and medium-low-tech companies influences the company's technological innovation breadth,

- To analyze how the importance of sources of information from customers, suppliers, consultants, and technology transfer institutes help low- and mediumlow-tech companies to improve their technological innovation breadth, and

- To show how the acquisition of machinery, hardware and software helps to improve the technological innovation breadth.

To meet these objectives the article proceeds as follows. Next, the authors provide a short background section, which identifies the study's key concepts and variables. Then, it follows a section that develops the study's hypotheses in greater detail. Besides, it is identified the data used for the study and methods for analysis. Next, the authors provide 
the study's results indicating significance and hypothesis acceptance. Later, it is presented a discussion of the results and the relevance of these to further our undestanding of lowand medium-low-tech company innovation. Finally, closing the article with a short conclusion.

\section{Background of the study}

In the following section, the authors present the basic concepts related to the variables of studies such as industries of low- and medium-low tech intensity, absorptive capacity, sources of information, technological acquisition, and company performance, leading onto hypothesis definition.

The level of technology intensity of an industry is able to be determined and used to classify an industry as low- and medium-low-tech. Kirner, Kinkel, \& Jaeger (2009) classified firms according a measure calculated by dividing internal research and development spending sales over a particular year. Their analysis established three categories: (1) high technological intensity, which were those companies with a had an indicator greater than 7\%; (2) medium technological intensity, which were those companies whose indicator is between $2.5 \%$ and $7 \%$; and (3) low-technology companies which are those with an indicator of less than $2.5 \%$. Heidenreich (2009) conducted a study based on the fourth Community Innovation Survey (CIS4) and found that companies belonging to the group of low- and medium-intensity technology industries tend to be characterized by innovation, which is concerned more with processes, organizing or marketing, while having a high dependence on the external supply of technologies in the form of machines, equipment and software. The role of formal and informal knowledge among companies has also been determined to be important for industries of low or medium technological intensity, as these industries have been found to learn beyond those activities directly related to research and development ((Sciascia, D’Oria, Bruni, \& Larrañeta, 2014); (Santamaría et al., 2009); (Jacobson \& Heanue, 2005)).

Absorptive capacity is one of the constructs that has had a great impact on the research of organizations. The development of different models of absorptive capacity has been due to the fact that the construct has attracted the interest of a great number of researchers due to the influence of the absorptive capacity in the development of competitive advantages and the performance of the company (Volberda, Foss, \& Lyles, 2010). Cohen \& Levinthal (1990) point out that the absorptive capacity is the ability of the company to recognize the value of new and external information, to assimilate it and to apply it for 
commercial purposes and for its critical innovative capabilities. Then, Zahra \& George (2002) propose a new model of absorptive capacity, indicating that it is a multidimensional construct. In this regard, they point out that there are four dimensions that make up the absorptive capacity of the company: Acquisition, assimilation, transformation and exploitation. Subsequently, Todorova \& Durisin (2007) criticize the work of Zahra \& George (2002) noting that the development of the absorptive capacity is a process of path dependence, and that the increase of the knowledge in the area of the experience driving the future development of capabilities.

Organizations gain knowledge through the interaction of internal and external sources of information (Laursen \& Salter, 2006). This external knowledge comes a range of West \& Bogers (2014), with specific sources of external knowledge being suppliers (Li \& Vanhaverbeke, 2009), customers (Grimpe \& Sofka, 2009), competitors (Lim, Chesbrough, \& Ruan, 2010), or universities (Fabrizio, 2009). While companies that use external and internal sources improve their innovative performance, the combined effect of these sources of knowledge is often not very clear (Frenz \& Ietto-Gillies, 2009).

According to a study carried out by Arbussa \& Coenders (2007) on mechanism that companies carry out to contribut to an improvement of their innovative capacityis to acquire machinery, equipment and hardware. Similarly, Frank, Cortimiglia, Ribeiro, \& De Oliveira, (2016) research on innovation in Brazil, noted that the purchase of machinery and equipment improves the results of innovation and processes in companies.

The technological innovation breadth, according to Gronum, Verreynne, \& Kastelle, (2012) is the result of combining responses from companies that have introduced a new or improved product or service or a new or improved process over the past three years.

\section{Hypothesis}

\subsection{Absorptive capacity and technological innovation breadth.}

The influence of absorptive capacity on innovation has been the subject of several investigations. Cohen \& Levinthal (1990) argued that the absorptive capacity is very important for the innovation process of the company, because it increases the speed and frequency of innovation. Innovations are therefore, primarily based on the firm's knowledge base (Kim \& Kogut, 1996). Similarly, Zahra \& George (2002) found a significant positive relationship between absorptive capacity and innovation, as these factors work together to establish the competitive advantage of the organization. This 
argument is supported by the empirical study of Knudsen \& Roman (2004), who also suggest that absorptive capacity is an important factor in predicting an organization's capacity for innovation.

Caloghirou, Kastelli, \& Tsakanikas (2004) investigated the extent to which the existing internal capabilities of firms and their interaction with external sources of knowledge affect their level of innovation. The findings of their research show that some capacities result from a protracted process of investment and accumulation of knowledge within companies and form what has been treated as the absorptive capacity of companies. In addition, the results show that both internal capabilities and openness to knowledge sharing are important for improving innovative performance. Wang \& Han (2011) carried out a study on SMEs in China, that validated knowledge properties and absorptive capacity as two inseparable determinants of innovation performance, while indicating that absorptive capacity moderates the relationship between the properties of knowledge and the performance of innovation. Ali \& Park (2016) developed a study of 195 Korean companies of various sizes and sectors, in which they validated that absorptive capacity is crucial to the organization's innovation and performance.

It is also important to mention that Ince, Imamoglu, \& Turkcan (2016) developed a theoretical model, which holds that absorptive capacity has a positive impact on technological innovation capacities and both together have a positive impact on innovation.

In this sense the following hypothesis can be proposed:

Hypothesis 1: Absorptive capacity improves the technological innovation breadth in companies

\subsection{Sources of information and technological innovation breadth}

It is clear that firms can improve their ability to innovate by carefully managing information that comes from relationships with suppliers, customers, and other resource providers, such as universities or government agencies (Kaufman, McAndrews, \& Wang, 2000). Yli-Renko, Autio, \& Sapienza (2001) consider that the acquisition of customer knowledge shows a positive influence on product innovation. In this sense, customers, as well as suppliers, can play an important role in the innovation process as they contribute to providing key information on technologies, markets and user needs (Díaz-Díaz \& De Saá-Peréz, 2007). While some innovative firms may devote little financial resources to formal R \& D activities, they achieve successful innovations due to the use of knowledge 
and applying experience of a wide range of external sources of information (Laursen \& Salter, 2006). Wu, Lin, \& Hsu (2007) found there to be a positive relationship, in which relations with customers and suppliers and product innovation appear to complement each other as firms acquire and apply external knowledge and skills. From the perspective of open innovation, the knowledge of an organization's sources of information customers and suppliers is therefore related to technological innovation of products and processes and, consequently, of business's success. On the basis of such arguments Delgado, De Castro, Navas, \& Cruz (2011), applied this complimentary perspective of knowledge to a sample of 251 Spanish companies in the manufacturing sector. The results provided empirical evidence on the influence of knowledge sources on innovation. The results reflected the important role of sources of information on product and/or process innovation, highlighting in greater measure the interorganizational relations maintained by the company, with its customers and suppliers.

Based on the above, the following hypothesis can be considered:

\section{Hypothesis 2: Sources of information are important to improvement of the technological innovation breadth of companies}

\subsection{Technological acquisition and technological innovation breadth}

Calvo (2000) argue that, in 1998, innovative companies in Spain not only invested significant R \& D shares, but also in the acquisition of machinery, the purchase of intangible technology, training and marketing. Therefore, we can say that they diversified their expenses in several activities.

Ahuja \& Katila (2001), it is important to clarify that it is not enough to acquire technology to increase innovation, but also to evaluate its impact, favorable or not, on innovation production. The benefits that can be received will depend on the number and nature of the knowledge elements that will be offered to the company that acquires them. Consideration should therefore be given to the statement by Calantone, Cavusgil, \& Zhao (2002) that "Innovative capacity is one of the most important determinants of company performance". In this sense, it could be assumed that if the acquisition of machinery, hardware, and software improves the company's innovative capacity this will improve the performance of the company. It can be assumed that the purchase of technological assets is a contribution to the improved performance of the company. Potters (2009) states that in order to implement new or improved products or processes, ie innovation activities, the purchase of machinery and equipment is required. Among advanced machinery, we 
have, for example, computer hardware, which is needed for the processes and products mentioned. This technology can be used directly because it is already incorporated in the equipment and machinery. As Santamaría et al. (2009) point out not only are the R \& D activities a source of innovation for the company but also the other types of activities including knowledge and experience gained from the use of advanced machinery and tools, which has been found to be a source of innovation for low- and medium-low-tech intensity companies. Huang, Arundel, \& Hollanders (2011) cite Pavitt (1984) to indicate that industrial sectors that are dominated by suppliers, such as textiles, leather and footwear manufacturers, which are also typical examples of low technology industries, tend to focus on their innovative capacity development efforts through the purchase of advanced machinery and equipment.

Further, Zuniga \& Crespi (2013) indicate that innovation strategies to used for are what allow technological product-innovation- and / or process innovationmay consist of: investment in research and development $(\mathrm{R} \& \mathrm{D})$; the acquisition of technology in the market through R \& D contracting, licensing technology and know-how; the contracting of technical and engineering services; and the acquisition of machinery and equipment that favor innovation.

Therefore, the following hypothesis is proposed:

Hypothesis 3: The acquisition of machinery, hardware and software contributes to improve the technological innovation breadth of companies.

\section{Methods}

For this empirical study, the authors use the data collected in the National Survey of Innovation in the Manufacturing Industry 2012, a survey applied to the Peruvian manufacturing sector companies to obtain information about their innovation processesdeterminants, obstacles and specific characteristics. This is third time that this survey has been conducted and is considered to have improved representativeness and reliability than previous versions.

The study was carried out in coordination with the Ministry of Economy and Finance (MEF), National Council of Science, Technology and Technological Innovation (Concytec) and the National Institute of Statistics and Informatics (INEI). INEI were responsible for data collection financed by the Inter-American Development Bank (IDB). The survey was designed and developed based on the methodological framework of the 
"Bogotá Manual", which allows for comparable indicators and results with other Latin American countries.

The survey was conducted during the reference period 2009-2012 and with a representative sample of 1220 companies, of large, medium and small, across the country' different regions. As such, the survey is considered to have inference at the national level. The design of this survey was developed based on the methodological framework of the "Bogotá Manual", which in turn will allow the elaboration of indicators comparable with the results of other countries in the Latin American region.

\subsection{Sample}

The development of the national survey allowed to obtain information from companies whose economic activity is included in section $\mathrm{C}$ (manufacturing industries), divisions 10 to 33, according to ISIC, revision 4. The survey was carried out in the regions of Lima, Arequipa, La Libertad, Áncash, Ica, Piura, Ucayali, Lambayeque, Junín and San Martín, in which more than $90 \%$ of the value of the production of the manufacturing activity at national level is generated. The information obtained from the 1220 companies surveyed covers the three consecutive years of 2009 to 2011.

\subsection{Obtaining the data}

According to INEI, responses were obtained through the direct interview, with each informant assigned by the companies considered in the sample. This exercise was carried out from the first days of September until mid-October of 2012 by trained interviewers. The field work resulted in 1,220 questionnaries carried out of which 1,121 were identified as manufacturing companies.

\subsection{Conceptual model}

Figure 1 shows the conceptual model that relates the three constructs: absorptive capacity, sources of information and technological acquisition with the technological innovation breadth. 


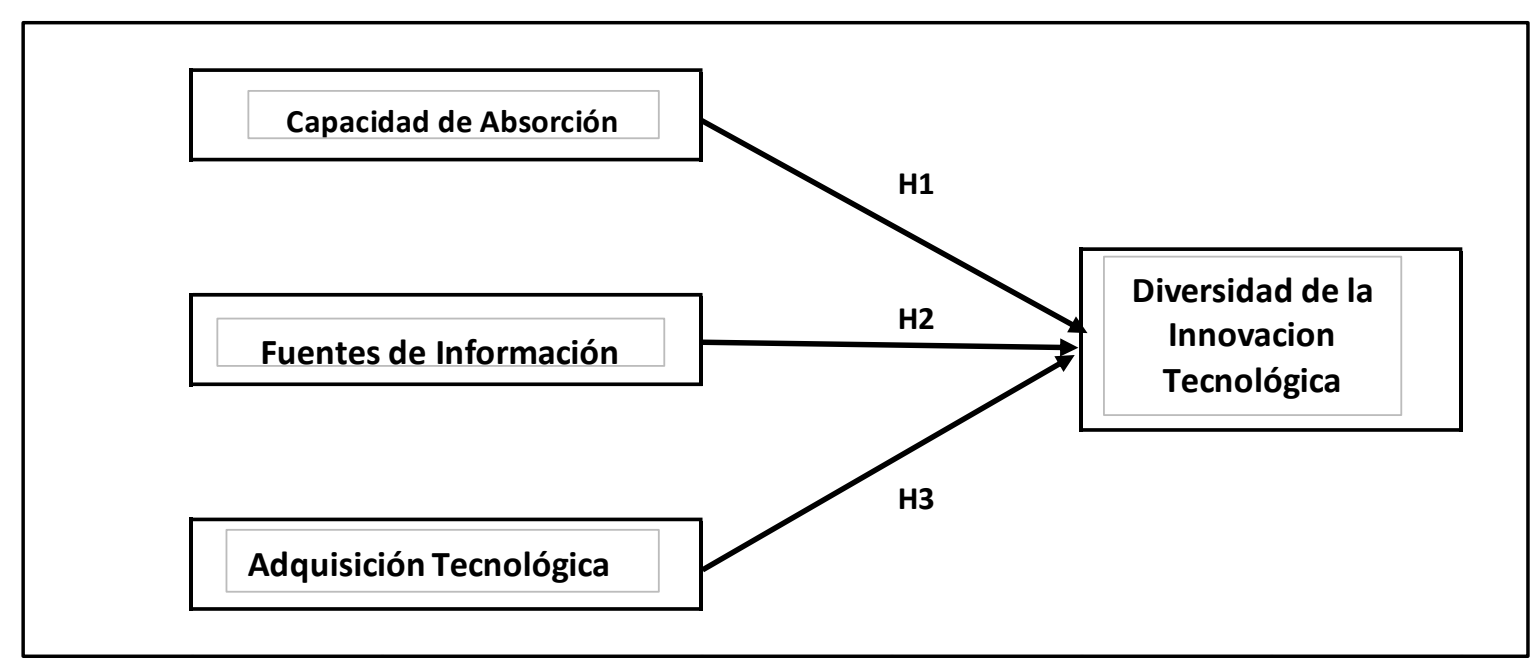

Figure 1. Conceptual model (Source: Own illustration).

Analysis and calculations were made by applying the SMART PLS version 3 using three (3) data groups specified by the following criteria, where: specification one includes all companies that participated in the 2012 manufacturing innovation survey, specification two includes only low- and medium-low-tech companies that participated in the 2012 manufacturing innovation survey, and specification three includes only the medium-high and high technology companies that participated in the 2012 manufacturing innovation survey.

\subsection{The measurement of the variables}

Below is a description of how absorptive capacity has been measured.

\subsubsection{Measurement of absorptive capacity}

Absorptive capacity is measured using the proposal of Escribano, Fosfuri, \& Tribó, (2009). In this sense, two variables are considered: (1) expenditure on research and technological development activities, both internal and external, and (2) training costs for innovation activities. These data were transformed by applying the logarithm in base 10 .

\subsubsection{Measuring sources of information}

In the questionnaire developed by INEI, Chapter VIII asks the respondents about the degree of importance of the sources of information that the company could have used for the development of innovation during the period 2009 to 2011.

The grades of importance were classified with the following criteria: None (1), low (2), medium (3) and high (4). 
Table 1 shows the different sources of information:

\begin{tabular}{|c|c|c|}
\hline Type of source & $\mathbf{N}^{\mathbf{o}}$ & Source of information \\
\hline Internal & 1 & Within the company or group of companies \\
\hline Market & $\begin{array}{l}3 \\
4 \\
5\end{array}$ & $\begin{array}{l}\text { Suppliers of equipment, materials, components or } \\
\text { software } \\
\text { Customers } \\
\text { Competitors } \\
\begin{array}{l}\text { Consultants, commercial laboratories or private } \\
\text { institutes of I +D }\end{array}\end{array}$ \\
\hline Institutional & $\begin{array}{l}6 \\
7\end{array}$ & $\begin{array}{l}\text { Universities or other research centers } \\
\text { Government or public institutes }\end{array}$ \\
\hline Other & $\begin{array}{l}8 \\
9 \\
10 \\
11 \\
12\end{array}$ & $\begin{array}{l}\text { Conferences, trade fairs, exhibitions } \\
\text { Scientific journals and technical trade publications } \\
\text { Professional and sectoral associations } \\
\text { Internet access } \\
\text { Other specify }\end{array}$ \\
\hline
\end{tabular}

Table 1. Different sources of information (Source: Based on INEI Survey 2012, own illustration)

Of these, the following sources of information were considered for the analysis: suppliers of equipment, materials, components or software; consultants, commercial laboratories or private R \& D institutes; conferences, trade fairs, exhibitions; scientific journals and technical trade publications; and professional and sectoral associations because they have a greater explanation in technological innovation.

\subsubsection{Measurement of technological acquisition}

The technological acquisition has been measured with the following variables:

The acquisition of capital machinery, i.e. the incorporation of machinery, tools or buildings linked to the introduction of improvements and / or innovations of products (goods or services), processes, organizational techniques and / or marketing (INEI Survey, 2012).

The acquisition of hardware, i.e. the acquisition, outsourcing or leasing of hardware specifically designed to introduce changes in products (goods or services), processes, organizational techniques and / or marketing (INEI Survey, 2012). 
The acquisition of software, i.e. the acquisition or leasing of software specifically designed to introduce changes in products (goods or services), processes, organizational techniques and / or marketing (INEI Survey, 2012).

These data were transformed by applying the logarithm in base 10 .

\subsubsection{The measurement of the technological innovation breadth of the company}

The measurement of the technological innovation breadth of the company is measured by the answers obtained from the following questions that have been formulated in the Innovation questionnaire (INEI Survey, 2012), which is presented in Table 2.

\begin{tabular}{|c|l|}
\hline Type of innovation & $\begin{array}{c}\text { In the years 2009-2011 the company was able to introduce or } \\
\text { incorporate a: }\end{array}$ \\
\hline \multirow{2}{*}{ Innovation in } & $\begin{array}{l}\text { 1. Good new? } \\
\text { product }\end{array}$ \\
& $\begin{array}{l}\text { 3. New service? } \\
\text { 4. Significantly improved service? }\end{array}$ \\
\hline Innovation in & 5. New process? \\
process & 6. Significantly improved process? \\
\hline
\end{tabular}

Table 2. Technological innovation of product and process (Source: Based on INEI Survey 2012, own illustration)

The answers are dichotomous, where if the answer is YES the value will be 1, and if the answer is NO the value will be 0 . The value of the variable diversity of innovation will be the result of adding the answers to questions 1,2, 3, 4, 5 and 6 .

\section{Results}

\subsection{Descriptive Statistics}

Table 3 provides respondent demographic characteristics: Age of the company (in years), number of employees and annual sales (thousands of Nuevos Soles). In total, there are 1121 manufacturing companies used for analysis; because there are companies with missing values that do not contribute to the study. 


\begin{tabular}{|c|c|}
\hline Demographics & Frequencies \\
\hline \multicolumn{2}{|l|}{ Age of company (in years) } \\
\hline$[6-10]$ & 217 \\
\hline [11-15] & 232 \\
\hline$[16-20]$ & 206 \\
\hline$>20$ & 466 \\
\hline Total & 1121 \\
\hline \multicolumn{2}{|l|}{ Number of employees } \\
\hline$<=50$ & 648 \\
\hline$[51-250]$ & 250 \\
\hline$>250$ & 226 \\
\hline Total & 1121 \\
\hline \multicolumn{2}{|c|}{ Annual sales (thousands of soles) } \\
\hline$<=540$ & 53 \\
\hline$<540-6120]$ & 499 \\
\hline$<6120-8280]$ & 53 \\
\hline$>8280$ & 516 \\
\hline Total & 1121 \\
\hline
\end{tabular}

Table 3. Demographic Characteristics (Based on INEI Survey 2012, own compilations).

The descriptive statistics and correlations of the 3 specifications are shown (see Annex 8.5); specification 1 which include all enterprises in the data processing, specification 2 which only considers low- and medium-low-tech enterprises and specification 3, which only considers medium-high and high-end enterprises technological intensity. Correlation analysis serves to measure the strength or degree of correlation between the variables under study, according to Bernal (2010). A criterion for assessing whether this explanatory capacity is low, medium or high is to take the values $0.1,0.3$ and 0.5 respectively, which offers as referents Cohen J. (1988). According to the study, the correlations of the measurable variables in each latent variable in the different specifications are above 0.3 ; indicating that there is a mean and high correlation within each latent variable. Therefore, it is appropriate to consider expenditures on research and technological development, and training costs for innovation activities in the latent variable Absorptive Capacity (ACAP); equipment and software suppliers, private consultants and institutes, conferences and exhibitions, scientific magazines, and professional associations in the latent variable Sources of Information (SOI); acquisition of capital machinery, acquisitions of hardware and acquisition of software in the latent variable Technological Acquisition (TECHNOLOGY). 


\subsection{Measurement model}

The measurement model requires that the following indicators be checked:

- The reliability of the model using Cronbach's alpha and the composite reliability index whose values must be greater than 0.7 (Hair, Sarstedt, Pieper, \& Ringle, 2012).

- Convergent validity using AVE (average variance extracted) whose value must be greater than 0.5 (Henseler, Ringle, \& Sinkovics, 2009).

- Multicollinearity using the Variance Inflation Factor (VIF) indicator whose reference value should be less than 5 (Hair et al., 2012).

- Discriminant validity by comparing the square root of AVE and correlations between variables. To verify the discriminant validity, the square root of the AVE must be greater than the correlation (Fornell \& Larcker, 1981).

It can be seen that, for all specifications using the composite reliability index, the minimum requirement of 0.7 is exceeded, which is not the case with Cronbach's alpha, which rarely exceeds the reference value; while for all specifications it can be seen that multicollinearity is controlled, with values lower than 5. When it is analyzed the convergent validity using AVE must be greater than 0.5; in most cases the condition is satisfies, however there is only one case in the third specification for the construct Source of Information the AVE is 0.491 almost 0.5 . Also, when the discriminante validity is analyzed; in all the cases the square root of the AVE is greater than correlations. Therefore, the measurements models can be accepted. Tables 4, 6 and 8 present the indicators of validity, reliability, coefficient of determination and multicollinearity for the three specifications, while tables 5,7 and 9 provides discriminant validity data for each specification measurement model. 


\begin{tabular}{|c|c|c|c|c|c|c|c|}
\hline Latent variable & $\begin{array}{l}\text { Description } \\
\text { of item }\end{array}$ & $\begin{array}{l}\text { Item } \\
\text { Loadings }\end{array}$ & $\begin{array}{l}\text { Cronbach's } \\
\text { alpha }\end{array}$ & $\begin{array}{l}\text { Composite } \\
\text { Reliability } \\
\text { (CR) }\end{array}$ & AVE & VIF & $R^{2}$ \\
\hline \multirow{2}{*}{$\begin{array}{l}\text { Absorptive } \\
\text { capacity (ACAP) }\end{array}$} & $\begin{array}{l}\text { Expenditure } \\
\text { on research } \\
\text { and } \\
\text { technological } \\
\text { development. }\end{array}$ & 0.869 & \multirow[t]{2}{*}{0.646} & \multirow[t]{2}{*}{0.850} & \multirow[t]{2}{*}{0.739} & \multirow[t]{2}{*}{1.508} & \multirow{10}{*}{0.454} \\
\hline & $\begin{array}{l}\text { Training } \\
\text { costs for } \\
\text { innovation } \\
\text { activities. }\end{array}$ & 0.850 & & & & & \\
\hline \multirow{5}{*}{$\begin{array}{l}\text { Sources of } \\
\text { Information (SOI) }\end{array}$} & $\begin{array}{l}\text { Equipment } \\
\text { and software } \\
\text { suppliers }\end{array}$ & 0.708 & \multirow{5}{*}{0.769} & \multirow{5}{*}{0.839} & \multirow{5}{*}{0.514} & \multirow{5}{*}{1.058} & \\
\hline & $\begin{array}{l}\text { Private } \\
\text { consultants } \\
\text { and institutes }\end{array}$ & 0.602 & & & & & \\
\hline & $\begin{array}{l}\text { Conferences } \\
\text { and } \\
\text { exhibitions }\end{array}$ & 0.782 & & & & & \\
\hline & $\begin{array}{l}\text { Scientific } \\
\text { magazines }\end{array}$ & 0.811 & & & & & \\
\hline & $\begin{array}{l}\text { Professional } \\
\text { associations }\end{array}$ & 0.660 & & & & & \\
\hline \multirow{3}{*}{$\begin{array}{l}\text { Technological } \\
\text { acquisition } \\
\text { (TECHNOLOGY) }\end{array}$} & $\begin{array}{l}\text { Acquisition } \\
\text { of capital } \\
\text { machinery. }\end{array}$ & 0.799 & \multirow{3}{*}{0.718} & \multirow{3}{*}{0.839} & \multirow{3}{*}{0.635} & \multirow{3}{*}{1.494} & \\
\hline & $\begin{array}{l}\text { Acquisition } \\
\text { of hardware. }\end{array}$ & 0.819 & & & & & \\
\hline & $\begin{array}{l}\text { Acquisition } \\
\text { of software. }\end{array}$ & 0.772 & & & & & \\
\hline \multicolumn{2}{|c|}{ Reference value } & & $>0.7$ & $>0.7$ & $>0.5$ & $<5$ & \\
\hline
\end{tabular}

Table 4. Specification one: Indicators of validity, reliability, coefficient of determination and multicollinearity (Source: Applying to SMART PLS software, own calculations)

\begin{tabular}{|c|c|c|c|c|}
\hline & ACAP & $\begin{array}{c}\text { Technological } \\
\text { Innovation Breadth }\end{array}$ & FI & TECHNOLOGY \\
\hline ACAP & $\mathbf{0 . 8 5 9}$ & & & \\
\hline $\begin{array}{c}\text { Technological } \\
\text { Innovation Breadth }\end{array}$ & 0.589 & $\mathbf{1 . 0 0}$ & & \\
\hline SOI & 0.217 & 0.198 & $\mathbf{0 . 7 1 7}$ & \\
\hline TECHNOLOGY & 0.570 & 0.603 & 0.195 & $\mathbf{0 . 7 9 7}$ \\
\hline
\end{tabular}

Table 5. Specification one: Discriminant validity (Comparison of square root of AVE and correlations) (Source: Applying to SMART PLS software, own calculations) 
The influence of absorptive capacity, sources of information and technological acquisition in the technological innovation breadth of manufacturing companies

\begin{tabular}{|c|c|c|c|c|c|c|c|}
\hline Latent variable & $\begin{array}{l}\text { Description } \\
\text { of item }\end{array}$ & $\begin{array}{l}\text { Item } \\
\text { Loadings }\end{array}$ & $\begin{array}{l}\text { Cronbach's } \\
\text { alpha }\end{array}$ & $\begin{array}{l}\text { Composite } \\
\text { Reliability } \\
\text { (CR) }\end{array}$ & AVE & VIF & $R^{2}$ \\
\hline \multirow{2}{*}{$\begin{array}{l}\text { Absorptive } \\
\text { capacity (ACAP) }\end{array}$} & $\begin{array}{l}\text { Expenditure } \\
\text { on research } \\
\text { and } \\
\text { technological } \\
\text { development. }\end{array}$ & 0.858 & \multirow[t]{2}{*}{0.630} & \multirow[t]{2}{*}{0.844} & \multirow[t]{2}{*}{0.730} & \multirow[t]{2}{*}{1.511} & \multirow{10}{*}{0.456} \\
\hline & $\begin{array}{l}\text { Training } \\
\text { costs for } \\
\text { innovation } \\
\text { activities. }\end{array}$ & 0.851 & & & & & \\
\hline \multirow{5}{*}{$\begin{array}{l}\text { Sources of } \\
\text { Information (SOI) }\end{array}$} & $\begin{array}{l}\text { Equipment } \\
\text { and software } \\
\text { suppliers }\end{array}$ & 0.738 & \multirow{5}{*}{0.775} & \multirow{5}{*}{0.842} & \multirow{5}{*}{0.519} & \multirow{5}{*}{1.066} & \\
\hline & $\begin{array}{l}\text { Private } \\
\text { consultants } \\
\text { and institutes }\end{array}$ & 0.586 & & & & & \\
\hline & $\begin{array}{l}\text { Conferences } \\
\text { and } \\
\text { exhibitions }\end{array}$ & 0.790 & & & & & \\
\hline & $\begin{array}{l}\text { Scientific } \\
\text { magazines }\end{array}$ & 0.806 & & & & & \\
\hline & $\begin{array}{l}\text { Professional } \\
\text { associations }\end{array}$ & 0.656 & & & & & \\
\hline \multirow{3}{*}{$\begin{array}{l}\text { Technological } \\
\text { acquisition } \\
\text { (TECHNOLOGY) }\end{array}$} & $\begin{array}{l}\text { Acquisition } \\
\text { of capital } \\
\text { machinery. }\end{array}$ & 0.790 & \multirow{3}{*}{0.701} & \multirow{3}{*}{0.831} & \multirow{3}{*}{0.622} & \multirow{3}{*}{1.500} & \\
\hline & $\begin{array}{l}\text { Acquisition } \\
\text { of hardware. }\end{array}$ & 0.813 & & & & & \\
\hline & $\begin{array}{l}\text { Acquisition } \\
\text { of software. }\end{array}$ & 0.762 & & & & & \\
\hline \multicolumn{3}{|c|}{ Reference value } & $>0.7$ & $>0.7$ & $>0.5$ & $<5$ & \\
\hline
\end{tabular}

Table 6. Specification two: Indicators of validity, reliability, coefficient of determination and multicollinearity (Source: Applying to SMART PLS software, own calculations)

\begin{tabular}{|l|c|c|c|c|}
\hline & ACAP & $\begin{array}{c}\text { Technological } \\
\text { Innovation Breadth }\end{array}$ & FI & TECHNOLOGY \\
\hline ACAP & $\mathbf{0 . 8 5 4}$ & & & \\
\hline $\begin{array}{l}\text { Technological } \\
\text { Innovation Breadth }\end{array}$ & 0.581 & $\mathbf{1 . 0 0}$ & & \\
\hline SOI & 0.227 & 0.216 & $\mathbf{0 . 7 2 0}$ & \\
\hline TECHNOLOGY & 0.571 & 0.611 & 0.212 & $\mathbf{0 . 7 8 9}$ \\
\hline
\end{tabular}

Table 7. Specification two: Discriminant validity (Comparison of square root of AVE and correlations) (Source: Applying to SMART PLS software, own calculations). 


\begin{tabular}{|c|c|c|c|c|c|c|c|}
\hline Latent variable & $\begin{array}{l}\text { Description } \\
\text { of item }\end{array}$ & $\begin{array}{c}\text { Item } \\
\text { Loadings }\end{array}$ & $\begin{array}{l}\text { Cronbach's } \\
\text { alpha }\end{array}$ & $\begin{array}{l}\text { Composite } \\
\text { Reliability } \\
\text { (CR) }\end{array}$ & AVE & VIF & $R^{2}$ \\
\hline \multirow{2}{*}{$\begin{array}{l}\text { Absorptive } \\
\text { capacity (ACAP) }\end{array}$} & $\begin{array}{l}\text { Expenditure } \\
\text { on research } \\
\text { and } \\
\text { technological } \\
\text { development. }\end{array}$ & 0.895 & \multirow{2}{*}{0.693} & \multirow{2}{*}{0.866} & \multirow{2}{*}{0.764} & \multirow{2}{*}{1.513} & \multirow{10}{*}{0.451} \\
\hline & $\begin{array}{l}\text { Training } \\
\text { costs for } \\
\text { innovation } \\
\text { activities. }\end{array}$ & 0.853 & & & & & \\
\hline \multirow{5}{*}{$\begin{array}{l}\text { Sources of } \\
\text { Information (SOI) }\end{array}$} & $\begin{array}{l}\text { Equipment } \\
\text { and software } \\
\text { suppliers }\end{array}$ & 0.560 & \multirow{5}{*}{0.746} & \multirow{5}{*}{0.826} & \multirow{5}{*}{0.491} & \multirow{5}{*}{1.040} & \\
\hline & $\begin{array}{l}\text { Private } \\
\text { consultants } \\
\text { and institutes }\end{array}$ & 0.673 & & & & & \\
\hline & $\begin{array}{l}\text { Conferences } \\
\text { and } \\
\text { exhibitions }\end{array}$ & 0.760 & & & & & \\
\hline & $\begin{array}{l}\text { Scientific } \\
\text { magazines }\end{array}$ & 0.820 & & & & & \\
\hline & $\begin{array}{l}\text { Professional } \\
\text { associations }\end{array}$ & 0.662 & & & & & \\
\hline \multirow{3}{*}{$\begin{array}{l}\text { Technological } \\
\text { acquisition } \\
\text { (TECHNOLOGY) }\end{array}$} & $\begin{array}{l}\text { Acquisition } \\
\text { of capital } \\
\text { machinery. }\end{array}$ & 0.828 & \multirow{3}{*}{0.771} & \multirow{3}{*}{0.866} & \multirow{3}{*}{0.682} & \multirow{3}{*}{1.482} & \\
\hline & $\begin{array}{l}\text { Acquisition } \\
\text { of hardware. }\end{array}$ & 0.840 & & & & & \\
\hline & $\begin{array}{l}\text { Acquisition } \\
\text { of software. }\end{array}$ & 0.810 & & & & & \\
\hline \multicolumn{3}{|l|}{ Reference value } & $>0.7$ & $>0.7$ & $>0.5$ & $<5$ & \\
\hline
\end{tabular}

Table 8. Specification three: Indicators of validity, reliability, coefficient of determination and multicollinearity (Source: Applying to SMART PLS software, own calculations)

\begin{tabular}{|l|c|c|c|c|}
\hline & ACAP & $\begin{array}{c}\text { Technological } \\
\text { Innovation Breadth }\end{array}$ & FI & TECHNOLOGY \\
\hline ACAP & $\mathbf{0 . 8 7 4}$ & & & \\
\hline $\begin{array}{l}\text { Technological } \\
\text { Innovation Breadth }\end{array}$ & 0.606 & $\mathbf{1 . 0 0}$ & & \\
\hline SOI & 0.194 & 0.145 & $\mathbf{0 . 7 0 1}$ & \\
\hline TECHNOLOGY & 0.570 & 0.582 & 0.132 & $\mathbf{0 . 8 2 6}$ \\
\hline
\end{tabular}

Table 9. Specification three: Discriminant validity (Comparison of square root of AVE and correlations) (Source: Applying to SMART PLS software, own calculations)

\subsection{Structural model}

After evaluating the measurement models, we proceed to estimate the structural model by applying the Smart PLS version 3 for each of the 3 specifications, and the results are 
shown below in table 10 containing the coefficients of the variables and the coefficient of determination.

\begin{tabular}{|lc|c|c|c|}
\hline & & $\begin{array}{c}\text { All the } \\
\text { companies }\end{array}$ & $\begin{array}{c}\text { Low y Low- } \\
\text { Medium } \\
\text { Tech }\end{array}$ & $\begin{array}{c}\text { High y } \\
\text { Medium- } \\
\text { High Tech }\end{array}$ \\
\hline Absorptive capacity (ACAP) & P-val & 0.356 & 0.337 & 0.402 \\
\hline \begin{tabular}{lcc|c|c|} 
Sources of Information (SOI) \\
Coef
\end{tabular} & P-val & 0.044 & 0.053 & 0.021 \\
\hline $\begin{array}{l}\text { Technological acquisition } \\
\text { (TECHNOLOGY) }\end{array}$ & Coef & 0.391 & 0.407 & 0.350 \\
\hline & P-val & 0 & 0 & 0 \\
\hline Coefficient of determination $\left(\boldsymbol{R}^{\mathbf{2}}\right)$ & P-val & 0 & 0.036 & 0.654 \\
\hline
\end{tabular}

Table 10. Shows the coefficients of the variables and the coefficient of determination of specifications 1, 2 and 3 (Source: Applying to SMART PLS software, own calculations)

As can be seen coefficients for the variables across the specifications are statistically significant at 5\% except for specification three's relationship coefficient between Sources of Information (SOI) and Technological Innovation Breadth. Analysis of the results using, Henseler et al. (2009) coefficient of determination, where values of of 0.19 reflects a weak relation, a value of 0.33 reflects a moderate relation, and a value of 0.67 , a substantial relation, infers that the three specifications possess a moderate relationship, with the highest value found for companies of high and medium-high technological intensity. Table 11 shows the analysis of these results with respect to the hypotheses proposed by each model.

\begin{tabular}{|l|c|c|c|}
\hline & Specification 1 & Specification 2 & Specification 3 \\
\hline Hypothesis 1 & Yes & Yes & Yes \\
\hline Hypothesis 2 & Yes & Yes & No \\
\hline Hypothesis 3 & Yes & Yes & Yes \\
\hline
\end{tabular}

Table 11. Analysis of the hypothesis proposed by each specification (Source: own illustration) 
In the specifications one and two all three hypotheses are accepted. However, for specification three, companies of medium-high and high technological intensity, we only accept hypotheses one and three. For this specification, hypothesis two that refers to the sources of information improving the technological innovation breadth is not accepted.

\section{Conclusions}

This analysis of low- and medium-low manufacturing companies compared to mediumhigh and high technological intensity allows us to present the following conclusions:

The development of a company's absorptive capacity allows manufacturing companies to improve the technological innovation breadth. The results of the research show that low and medium-low tech companies face medium-high and high technological intensity, evidencing that research and technological development expenses together with training expenses for innovation activities improve the performance of the innovation of the company. In both specifications, these measurable variables are important for improving the breadth of technological innovation.

When comparing the importance of sources of information in low- and medium-low-tech enterprises compared to medium- and medium-high technology companies, it can be seen that in both sectors, the information that comes from of scientific journals and commercial publications allows to improve the technological innovation breadth. On the other hand, there is a difference between the source of information of suppliers and consultants; the suppliers of equipment, materials, components or software have a greater impact on companies of medium-high and high technological intensity; and consultants, commercial laboratories or private R \& D institutes, a greater importance in low- and medium-lowtech enterprises.

The acquisition of equipment, machinery, hardware and software has been constituted as the acquisition of incorporade technology that improves the company' innovative diversity (Huang et al., 2011) and thus contributes to improved company performance. In this sense, companies should selectively increase this type of acquisitions to increase their performance. In the medium-high and high technological intensity companies, a greater importance of the technological acquisition is presented in front of the companies of low and low-medium technological intensity. To be more specific, hardware acquisition has a greater importance in medium-high and high technology companies.

In the implications for researchers, this investigation has been conducted on a sample of manufacturing companies from information obtained in the survey of technological 
innovation carried out in 2012 by INEI and the Peruvian Ministry of Production. Three specifications of data were analyzed: (1) all companies, (2) low and medium-low technology companies; and (3) medium-high and high technology companies.

The results verified across the three specifications that absorptive capacity has some influence on the performance of the company supporting Volberda et al. (2010) observation that absorptive capacity improves the technological innovation breadth.

On the other hand, analysis of the degree of importance of sources of information improves the technological innovation breadth, verification was abtained for specifications 1 and 2 and concurs with Frenz \& Ietto-Gillies (2009) and FerrerasMéndez, Newell, Fernández-Mesa, \& Alegre (2015) findings. There is an exception with the third specification, consisting of medium-high and high technological intensity companies, rejecting the hypothesis, because other sources of information could improve the technological innovation breadth.

In terms of the role of technological acquisition to improve the technological innovation breadth, this statement was verified for all three specifications. The results are in agreement with Santamaría et al. (2009) finding that companies manage to develop innovations through the acquisition of machinery, equipment and software.

In the implications for researchers, managers may use the results to develop their own innovative capacity. To do this, the three variables used here can be applied: absorptive capacity, access to sources of information and acquisition of machinery, hardware, and software. In terms of the development of the absorptive capacity managers can consider to enhance a firm's capacity by increasing training costs to improve the skills and knowledge of the workforce to identify or propose process and product innovations. Managers may also consider the company's expenditure on research and technological development activities, both internal and external, while encouraging the use of external sources of information such as joining associations, subscribing to magazines, attending conferences, and improving engagement with consultants and suppliers. Lastly, managers may seek to improve their acquisition of knowledge and technology through the purchase of machinery and equipment that allows the improvement of the technological innovation breadth of the company.

The survey was conducted in 2012 and asks for information corresponding to the period 2009 to 2011. For this study, we have limited ourselves to analyzing the information corresponding to the year 2011. To improve the analysis and consistency of the 
hypotheses it would be convenient to analyze information corresponding to future periods.

While the data is considered robust, it is limited in that it lack some context. As such It is suggested that additional research be carried out to gather further characteristics of firms undertaking innovations, or to specify and contrast industrial sectors. Likewise, it may be possible to identify which of the activities of innovation has greater impact in the advancement of products, processes and non-technological innovation. 


\section{REFERENCES}

Ahuja, G., \& Katila, R. (2001). Technological acquisitions and the innovation performance of acquiring firms: A longitudinal study. Strategic management journal, 22(3), 197-220.

Ali, M., \& Park, K. (2016). The mediating role of an innovative culture in the relationship between absorptive capacity and technical and non-technical innovation. Journal of Business Research, 69(5), 1669-1675.

Arbussa, A., \& Coenders, G. (2007). Innovation activities, use of appropriation instruments and absorptive capacity: Evidence from Spanish firms. Research Policy, 36(10), 1545-1558.

Bernal, A. (2010). Metodología de la investigación: administración, economía, humanidades y ciencias sociales. Colombia: Prentice Hall.

Calantone, R. J., Cavusgil, S. T., \& Zhao, Y. (2002). Learning orientation, firm innovation capability, and firm performance. Industrial marketing management, 31(6), 515-524.

Caloghirou, Y., Kastelli, I., \& Tsakanikas, A. (2004). Internal capabilities and external knowledge sources: complements or substitutes for innovative performance? Technovation, 24(1), 29-39.

Calvo, J. L. (2000). Una caracterización de la innovación tecnológica en los sectores manufactureros españoles: Algunos datos. Economía Industrial, 331, 139-150.

Cohen, J. (1988). Statistical Power Analysis for the Behavioral Sciences (2nd ed.). New Jersey: Lawrence Erlbaum Associates.

Cohen, W. M., \& Levinthal, D. A. (1990). Absorptive capacity: A new perspective on learning and innovation. Administrative science quarterly, 128-152.

Delgado, M., De Castro, G., Navas, J., \& Cruz, J. (2011). Social capital, relational capital and technological innovation. Empirical evidence in Spanish high and medium-high technology manufacturing firms. Cuadernos de Economía y Dirección de la Empresa, 207-221.

Díaz-Díaz, N., \& De Saá-Peréz, P. (2007). El Papel de los Recursos Humanos de I+D en la Absorción del Conocimiento Adquirido mediante Alianzas. Congreso Nacional de $A C E D E$. Sevilla.

Escribano, A., Fosfuri, A., \& Tribó, J. A. (2009). Managing external knowledge flows: The moderating role of absorptive capacity. Research policy, 38(1), 96-105.

Fabrizio, K. R. (2009). Absorptive capacity and the search for innovation. Research Policy, 38(2), 255-267. 
Ferreras-Méndez, J. L., Newell, S., Fernández-Mesa, A., \& Alegre, J. (2015). Depth and breadth of external knowledge search and performance: The mediating role of absorptive capacity. Industrial Marketing Management, 47, 86-97.

Fornell, C., \& Larcker, D. F. (1981). Structural equation models with unobservable variables and measurement error: Algebra and statistics. Journal of marketing research, 382-388.

Frank, A. G., Cortimiglia, M. N., Ribeiro, J. L., \& De Oliveira, L. S. (2016). The effect of innovation activities on innovation outputs in the Brazilian industry: Marketorientation vs. technology-acquisition strategies. Research Policy, 45(3), 577-592.

Frenz, M., \& Ietto-Gillies, G. (2009). The impact on innovation performance of different sources of knowledge: Evidence from the UK Community Innovation Survey. Research Policy, 38(7), 1125-1135.

Grimpe, C., \& Sofka, W. (2009). Search patterns and absorptive capacity: Low-and hightechnology sectors in European countries. Research Policy, 38(3), 495-506.

Gronum, S., Verreynne, M. L., \& Kastelle, T. (2012). The role of networks in small and medium-sized enterprise innovation and firm performance. Journal of Small Business Management, 50(2), 257-282.

Hair, J. F., Sarstedt, M., Pieper, T. M., \& Ringle, C. M. (2012). The use of partial least squares structural equation modeling in strategic management research: a review of past practices and recommendations for future applications. Long range planning, 45(5), 320340 .

Heidenreich, M. (2009). Innovation patterns and location of European low-and mediumtechnology industries. Research Policy, 38(3), 483-494.

Heidenreich, M., Hirsch-Kreinsen, H., \& Jacobson, D. (2008). Low-tech industries between traded and untraded interdependencies: a dynamic concept of industrial complementarities. Innovation in Lowtech Firms and Industries, Hirsch-Kreisen H., Jacobson D.(eds.), Edward Elgar, Cheltenham, UK and Northampton, MA, USA, 22145.

Henseler, J., Ringle, C. M., \& Sinkovics, R. R. (2009). The use of partial least squares path modeling in international marketing. New challenges to international marketing, 277-319.

Huang, C., Arundel, A., \& Hollanders, H. (2011). How firms innovate. In DIME Final Conference. Maastricht.

Ince, H., Imamoglu, S. Z., \& Turkcan, H. (2016). The Effect of Technological Innovation Capabilities and Absorptive Capacity on Firm Innovativeness: A Conceptual Framework. Procedia-Social and Behavioral Sciences, 235, 764-770. 
INEI Survey. (2012). Perú: Encuesta Nacional de Innovación en la Industria Manufacturera, 2012- Principales Resultados. Obtenido de Cuestionario 79-90: http://innovacion.enlacesred.org/pdf/peru/Peru_Manufacturera.pdf

Jacobson, D., \& Heanue, K. (2005). Policy conclusions and recommendations. Journal of mental changes, 11(1-2), 359-416.

Kaufman, R., McAndrews, J., \& Wang, Y. (2000). Opening the "black box" of network externalities in network adoption. Information Systems Research, 61-82.

Kim, D. J., \& Kogut, B. (1996). Technological platforms and diversification. Organization Science, 7(3), 283-301.

Kirner, E., Kinkel, S., \& Jaeger, A. (2009). Innovation paths and the innovation performance of low-technology firms-An empirical analysis of German industry. Research Policy, 38(3), 447-458.

Knudsen, H. K., \& Roman, P. M. (2004). Modeling the use of innovations in private treatment organizations: The role of absorptive capacity. Journal of substance abuse treatment, 26(1), 51-59.

Krammer, S. M. (2016). The role of diversification profiles and dyadic characteristics in the formation of technological alliances: Differences between exploitation and exploration in a low-tech industry. Research Policy, 45(2), 517-532.

Laursen, K., \& Salter, A. (2006). Open for innovation: the role of openness in explaining innovation performance among UK manufacturing firms. Strategic management journal, 27(2), 131-150.

Li, Y., \& Vanhaverbeke, W. (2009). The effects of inter-industry and country difference in supplier relationships on pioneering innovations. Technovation, 29(12), 843-858.

Lim, K., Chesbrough, H., \& Ruan, Y. (2010). Open innovation and patterns of R\&D competition. International Journal of Technology Management, 52(3/4), 295-321.

Pavitt, K. (1984). Sectoral patterns of technical change: towards a taxonomy and a theory. Research policy, 13(6), 343-373.

Potters, L. (2009). Innovation input and output: differences among sectors. Communities, (10), 38.

Robertson, P., Smith, K., \& Von Tunzelmann, N. (2009). Innovation in low-and mediumtechnology industries. Research Policy, 38(3), 441-446.

Santamaría, L., Nieto, M. J., \& Barge-Gil, A. (2009). Beyond formal R\&D: Taking advantage of other sources of innovation in low-and medium-technology industries. Research Policy, 38(3), 507-517. 
Sciascia, S., D’Oria, L., Bruni, M., \& Larrañeta, B. (2014). Entrepreneurial Orientation in low-and medium-tech industries: The need for Absorptive Capacity to increase performance. European management journal, 32(5), 761-769.

Todorova, G., \& Durisin, B. (2007). Absorptive capacity: Valuing a reconceptualization. Academy of management review, 32(3), 774-786.

Volberda, H. W., Foss, N. J., \& Lyles, M. A. (2010). Perspective-absorbing the concept of absorptive capacity: how to realize its potential in the organization field. Organization science, 21(4), 931-951.

Wang, C., \& Han, Y. (2011). Linking properties of knowledge with innovation performance: the moderate role of absorptive capacity. Journal of Knowledge Management, 15(5), 802-819.

West, J., \& Bogers, M. (2014). Leveraging external sources of innovation: a review of research on open innovation. Journal of Product Innovation Management, 31(4), 814831.

Wu, S.-H., Lin, L.-Y., \& Hsu, M.-Y. (2007). Intellectual capital, dynamic capabilities and innovative performance of organisations. International Journal of Technology Management, 279-296.

Yli-Renko, H., Autio, E., \& Sapienza, H. (2001). Social capital, knowledge acquisitions, and knowledge exploitation in young technology-based firms. Strategic Management Journal, 587-613.

Zahra, S. A., \& George, G. (2002). Absorptive capacity: A review, reconceptualization, and extension. Academy of management review, 27(2), 185-203.

Zuniga, P., \& Crespi, G. (2013). Innovation strategies and employment in Latin American firms. Structural Change and Economic Dynamics, 24, 1-17. 
ANNEXES

Classification of companies according to their technological intensity according to OECD.

OECD Directorate for Science, Technology and Industry

Economic Analysis and Statistics Division

\section{ISIC REV. 3 TECHNOLOGY INTENSITY DEFINITION}

Classification of manufacturing industries into categories based on R\&D intensities

High-technology industries

Aircraft and spacecraft

Pharmaceuticals

Office, accounting and computing machinery

Radio, TV and communciations equipment

Medical, precision and optical instruments

Medium-low-technology industries

Building and repairing of ships and boats

Rubber and plastics products

Coke, refined petroleum products and nuclear fuel

Other non-metallic mineral products

Basic metals and fabricated metal products
Medium-high-technology industries

Electrical machinery and apparatus, n.e.c

Motor vehicles, trailers and semi-trailers

Chemicals excluding pharmaceuticals

Railroad equipment and transport equipment, n.e.c

Machinery and equipment, n.e.c.

Low-technology industries

Manufacturing, n.e.c.; Recycling

Wood, pulp, paper, paper products, printing and publishing

Food products, beverages and tobacco

Textiles, textile products, leather and footwear

Figure 2. Classification of the manufacturing companies according to technological intensity (Source: OECD 2011)

Classification of manufacturing enterprises according to their technological intensity and according to the two-digit ISIC code.

\begin{tabular}{|c|c|c|c|c|}
\hline Economic Activity & Division & $\begin{array}{c}\text { All } \\
\text { companies }\end{array}$ & $\begin{array}{c}\text { The } \\
\text { companies of } \\
\text { low- and low- } \\
\text { medium }\end{array}$ & $\begin{array}{c}\text { The } \\
\text { companies } \\
\text { of } \\
\text { medium- } \\
\text { high and } \\
\text { high }\end{array}$ \\
\hline Manufacture of food products & 10 & 116 & 116 & 0 \\
\hline Manufacture of beverages & 11 & 40 & 40 & 0 \\
\hline Manufacture of textiles & 13 & 49 & 49 & 0 \\
\hline Manufacture of wearing apparel & 14 & 52 & 52 & 0 \\
\hline $\begin{array}{c}\text { Manufacture of leather and related } \\
\text { products }\end{array}$ & 15 & 30 & 30 & 0 \\
Table 12: continued & & & & \\
\hline
\end{tabular}




\begin{tabular}{|c|c|c|c|c|}
\hline Economic Activity & Division & $\begin{array}{c}\text { All } \\
\text { companies }\end{array}$ & $\begin{array}{l}\text { The } \\
\text { companies of } \\
\text { low- and low- } \\
\text { medium }\end{array}$ & $\begin{array}{c}\text { The } \\
\text { companies } \\
\text { of } \\
\text { medium- } \\
\text { high and } \\
\text { high }\end{array}$ \\
\hline $\begin{array}{l}\text { Wood production and manufacture of } \\
\text { wood and cork products, except } \\
\text { furniture; manufacture of articles of } \\
\text { straw and plaiting materials }\end{array}$ & 16 & 48 & 48 & 0 \\
\hline $\begin{array}{l}\text { Manufacture of paper and paper } \\
\text { products }\end{array}$ & 17 & 45 & 45 & 0 \\
\hline Printing and playback of recordings & 18 & 36 & 36 & 0 \\
\hline $\begin{array}{l}\text { Manufacture of coke and products of } \\
\text { petroleum refining }\end{array}$ & 19 & 15 & 15 & 0 \\
\hline $\begin{array}{l}\text { Manufacture of chemical substances and } \\
\text { products }\end{array}$ & 20 & 57 & 0 & 57 \\
\hline $\begin{array}{l}\text { Manufacture of pharmaceuticals, } \\
\text { medicinal chemicals and botanical } \\
\text { products for pharmaceutical use }\end{array}$ & 21 & 30 & 0 & 30 \\
\hline $\begin{array}{l}\text { Manufacture of rubber and plastic } \\
\text { products }\end{array}$ & 22 & 57 & 57 & 0 \\
\hline $\begin{array}{l}\text { Manufacture of other non-metallic } \\
\text { mineral products }\end{array}$ & 23 & 100 & 100 & 0 \\
\hline Manufacture of basic metals & 24 & 104 & 104 & 0 \\
\hline $\begin{array}{l}\text { Manufacture of fabricated metal } \\
\text { products, except machinery and } \\
\text { equipment }\end{array}$ & 25 & 50 & 50 & 0 \\
\hline $\begin{array}{l}\text { Manufacture of computer, electronic } \\
\text { and optical products }\end{array}$ & 26 & 17 & 0 & 17 \\
\hline Manufacture of electrical equipment & 27 & 54 & 0 & 54 \\
\hline $\begin{array}{c}\text { Manufacture of machinery and } \\
\text { equipment n.c.p. }\end{array}$ & 28 & 35 & 0 & 35 \\
\hline $\begin{array}{l}\text { Manufacture of motor vehicles, trailers } \\
\text { and semi-trailers }\end{array}$ & 29 & 48 & 0 & 48 \\
\hline $\begin{array}{c}\text { Manufacture of other transport } \\
\text { equipment }\end{array}$ & 30 & 24 & 0 & 24 \\
\hline Manufacture of furniture & 31 & 44 & 44 & 0 \\
\hline Other manufacturing & 32 & 45 & 45 & 0 \\
\hline $\begin{array}{c}\text { Repair and installation of machinery and } \\
\text { equipment }\end{array}$ & 33 & 25 & 25 & 0 \\
\hline TOTAL & & 1121 & 856 & 265 \\
\hline
\end{tabular}

Table 12. Number of companies according to ISIC code (Source: Based on the information available in the database of the 2012 manufacturing innovation survey, own compilations) 


\section{Structural Model}

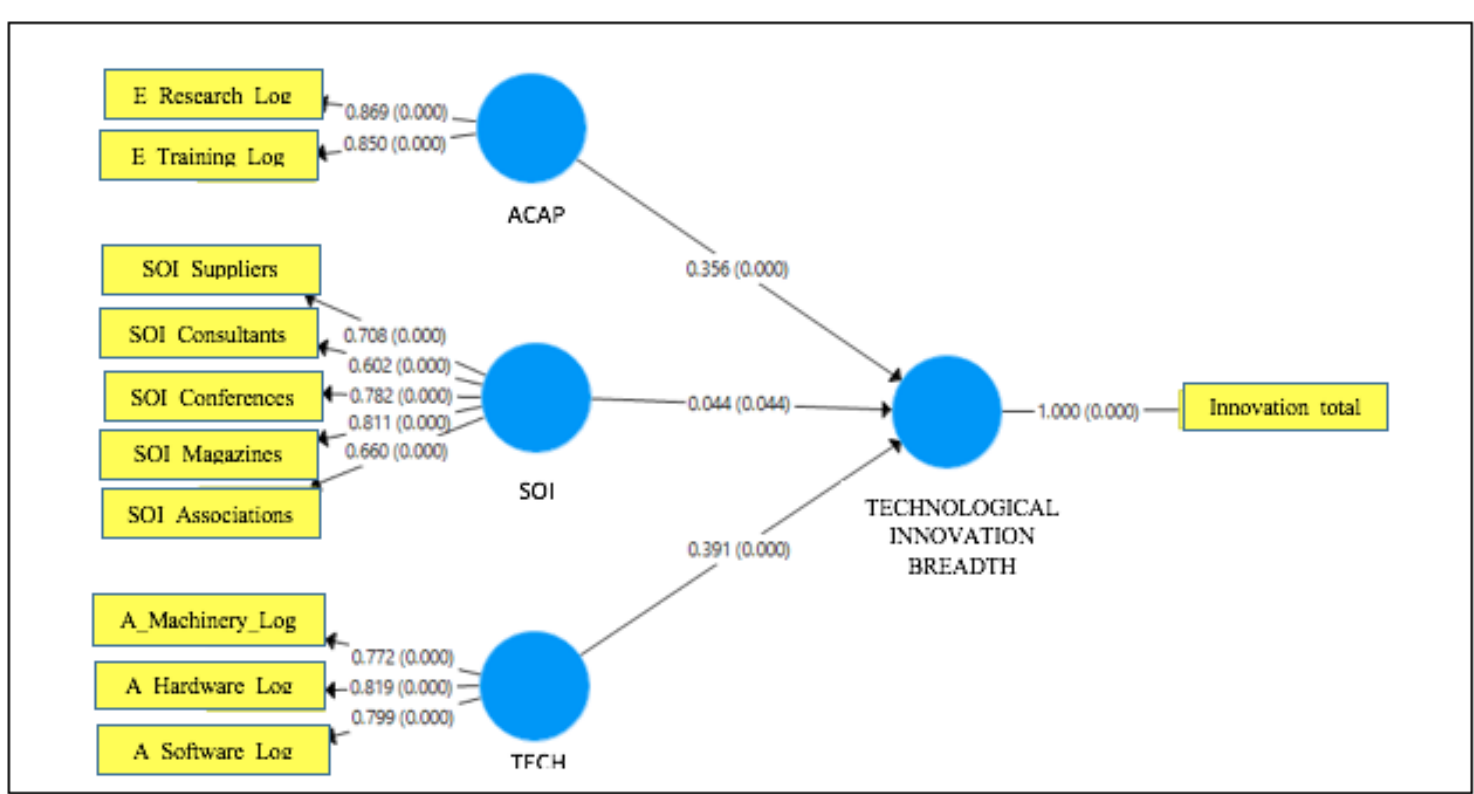

Figure 3. Graphical representation of the PATH diagram for the structural model of all the companies (Source: PATH diagram applied to SMART PLS software)

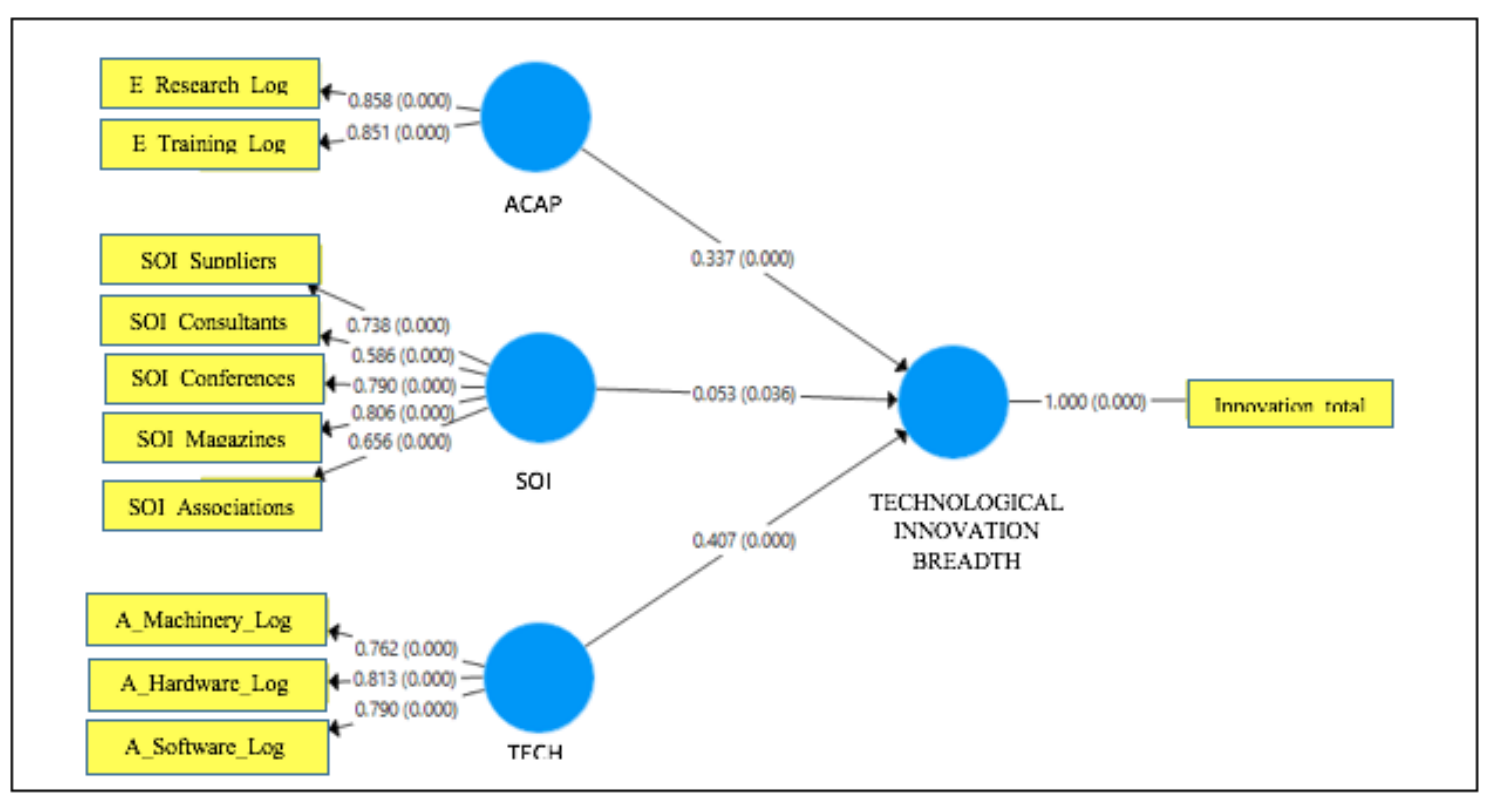

Figure 4. Graphical representation of the PATH diagram for the measurement model of the companies with low and low-medium technological intensity (Source: PATH diagram applied to SMART PLS software) 


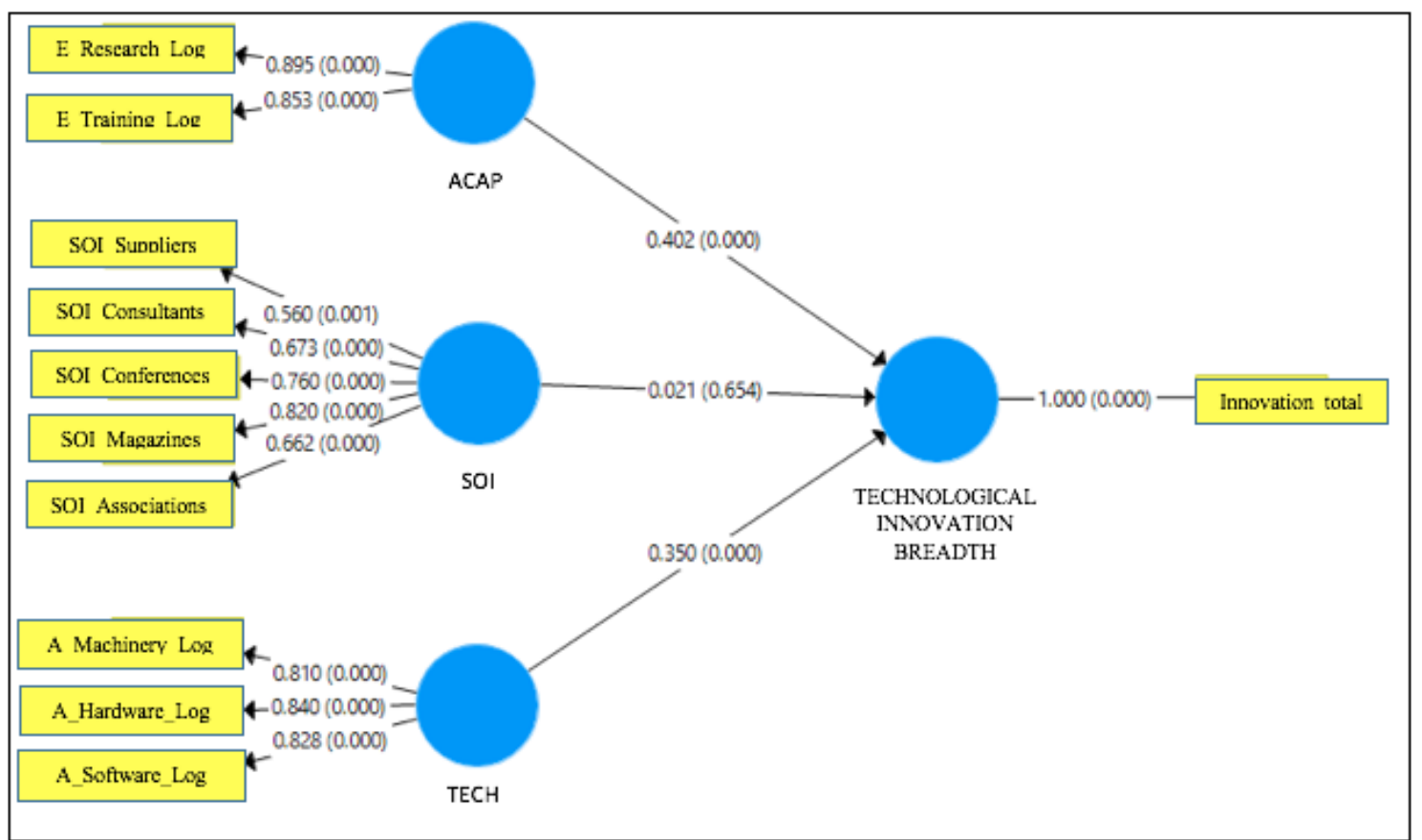

Figure 5. Graphical representation of the PATH diagram for the measurement model of companies with medium and medium-high technological intensity (Source: PATH diagram applied to SMART PLS software) 